\title{
Instruments to measure patient experience in hospitals: a scoping review
}

\author{
Instrumentos para avaliar a experiência do paciente em hospitais: \\ uma revisão de escopo
}

\author{
Juliana Maria Savio Bernardo ${ }^{1}$ (D), Glauco Henrique de Sousa Mendes ${ }^{1}$ (D), \\ Fabiane Letícia Lizarelli ${ }^{1}$ (D), Meliza Goi Roscani ${ }^{1}$ \\ ${ }^{1}$ Universidade Federal de São Carlos - UFSCar, Programa de Pós-graduação de Gestão de Organizações e \\ Sistemas Públicos, São Carlos, SP, Brasil. E-mail: glauco@dep.ufscar.br
}

How to cite: Bernardo, J. M. S., Mendes, G. H. S., Lizarelli, F. L., \& Roscani, M. G. (2022). Instruments to measure patient experience in hospitals: a scoping review. Gestão \& Produção, 29, e0821. https://doi.org/10.1590/1806-9649-2022v29e0821

\begin{abstract}
Patient experience (PE) has been associated with patients' perception of care services, organizational culture, and interactions experienced by patients. This article aims to characterize the process of measuring adult PE in general hospitals. Therefore, a scoping review (Scoping Review) in a sample of 51 empirical articles dealing with the assessment of PE was analyzed. The results show the predominance of quantitative PE measurement methods. HCAHPS is the most used instrument to evaluate PE. It was also possible to identify the attributes and dimensions (independent variables) considered in the PE measurement. In this case, the relational aspects between patients and health professionals have received great attention in the PE. Measures such as patient experience, satisfaction, quality, and loyalty have been used as PE outcomes (dependent variables). The article contributes to understanding the operationalization and measurement of PE by emphasizing the attributes and dimensions that have been considered in PE measurement, which can be useful for researchers and healthcare professionals interested in evaluating and identifying discrepancies in healthcare services.
\end{abstract}

Keywords: Patient experience; Measurement; Hospital; Scoping review.

Resumo: $A$ experiência do paciente (EP) tem sido associada à percepção dos pacientes em relação aos serviços de cuidado, à cultura organizacional e às interações vivenciadas pelos pacientes. Este artigo tem o objetivo de caracterizar o processo de mensuração da EP adulto em hospitais gerais. Para tanto, uma revisão de escopo (Scoping Review), em uma amostra de 51 artigos empíricos que tratam da avaliação da EP, foi realizada. Os resultados evidenciam a predominância dos métodos quantitativos para a mensuração da EP. Entre os instrumentos usados para avaliar a EP, o HCAHPS é o mais utilizado. Foram identificados os atributos e as dimensões (variáveis independentes) considerados na mensuração da EP. Neste caso, os aspectos relacionais entre os pacientes e os profissionais de saúde têm recebido grande atenção na EP. Medidas, como experiência do paciente, satisfação, qualidade e lealdade, têm sido usadas como resultados (variáveis dependentes) da EP. O artigo auxilia na compreensão da operacionalização e mensuração da EP ao apontar os principais instrumentos de avaliação, os atributos, as dimensões e os resultados que vêm sendo considerados na EP, o que pode ser útil

Received July 21, 2021 - Accepted Sept. 20, 2021

Financial support: None.

This is an Open Access article distributed under the terms of the Creative Commons Attribution License, which permits unrestricted use, distribution, and reproduction in any medium provided the original work is properly cited. 
para os pesquisadores e gestores de hospitais interessados em avaliar e em identificar discrepâncias nos serviços de saúde prestados.

Palavras-chave: Experiência do paciente; Mensuração; Hospital; Revisão de escopo.

\section{Introduction}

The concept of customer experience has become important in the management area, as creating positive customer experiences increases the chances of satisfaction and loyalty, in addition to increasing the competitive advantages to companies (Pine \& Gilmore, 1998; McColl-Kennedy et al., 2015; Mosavi et al., 2018; Silva et al., 2021). The customer experience is made by the perceptions that customers develop when they come into direct (e.g., personal service) or indirect (e.g., advertising) contact with different aspects of the company providing the product or service (Meyer \& Schwager, 2007; Verhoef et al., 2009). Therefore, the customer experience is a multidimensional and holistic construct, involving cognitive, affective, emotional, social, and physical customer responses concerning the company, brand, product, or service (Maklan, 2012; Verhoef et al., 2009). The customer experience involves activities at different stages, such as research, purchase, consumption, disposition, and other related activities (Verhoef et al., 2009).

In the service sector, customer experience has been investigated in banks (e.g., Mbama \& Ezepue, 2018), hospitality (e.g., Kandampully et al., 2018), and retail (e.g. Bustamante \& Rubio, 2017). In healthcare, the concept of customer experience, called patient experience (PE), had a fast approval among researchers and healthcare professionals (Wolf \& Jason, 2014; Rapport et al., 2019). PE reflects the quality of services from the patient's perspective and it has been a concern of health organizations (Wardhani et al., 2009; Macinati, 2008; Rapport et al., 2019; Rodrigues, 2019).

PE, according to Rodrigues (2019, p.19), "[...] includes aspects such as easy access to information, the way to respond to requests, respectful treatment, listening to the patient's needs and the compliance with individual values [...]". PE is not a simple concept and, it is often confused with other attributes, such as satisfaction, loyalty, and engagement (LaVela \& Gallan, 2014; Rodrigues, 2019). However, Wolf \& Jason (2014) point out that PE is more than customer satisfaction. For the authors, it is associated with patients' perception of care, organizational culture, and interactions experienced by patients. Beryl Institute proposes another seminal definition for PE, pointing to it as "[...] the sum of all interactions, shaped by an organization's culture, that influence patient perceptions throughout the care process" (The Beryl Institute, 2020). Thus, the use of slightly different conceptualizations for PE can lead to different interpretations of this phenomenon. Therefore, multiple conceptualizations can generate difficulties in their operationalization and measurement (Wolf \& Jason 2014; Rapport et al., 2019). Therefore, understanding how PE has been evaluated, through attributes and dimensions, can contribute to better understanding the phenomenon and, consequently, improve PE in health organizations (Beattie et al., 2015; Rapport et al., 2019).

The measurement of PE has been the focus of investigation in several studies (e.g., LaVela \& Gallan, 2014; Beattie et al., 2015; Male et al., 2017). Several quantitative and qualitative methods have been used to measure PE. Among the quantitative instruments are the Picker Patient Experience Questionnaire - PPE (e.g, LusillaPalacios \& Castellano-Tejedor, 2017), the Hospital Consumer Assessment of 
Healthcare Providers and System - HCAHPS (e.g., Banka et al., 2015), and Press Ganey (e.g, Heyworth et al., 2014). Among the qualitative methods, interviews and focus groups stand out (e.g., Sofaer et al., 2005; Kuis \& Goossensen, 2017; Webster et al., 2019). Despite the multiplicity of instruments, there is no consensus among authors about the measurement items (attributes and dimensions) that should be considered to measure PE (LaVela \& Gallan, 2014; Beattie et al., 2015).

Motivated by this research gap and recognizing the importance of $\mathrm{PE}$ for improving the quality of health services (LaVela \& Gallan, 2014; Beattie et al., 2015; Male et al., 2017), this article aims to examine how PE has been measured through a scoping review, in a sample of 51 articles on the subject. Considering that the customer experience (as well as that of the patient) depends on the context in which it takes place (Silva et al., 2021), we chose to investigate studies that evaluated the experience of adult patients in hospitals. The choice is justified, as a scoping review is adequate to identify concepts that form a certain research topic, especially when this topic is not yet consolidated (Arksey \& O'Malley, 2005; Peterson et al., 2017). Therefore, descriptive (e.g., year, country, journals, most cited studies, and, research strategies) and content analyses were carried out to identify the main assessment instruments, the evaluated attributes, and the main results considered of PE.

The article presents three main contributions. First, measuring patients' experience is a concern in the healthcare area, however, the conceptualization of PE lacks the conceptual clarity that, in turn, challenges its accurate assessment. Thus, this article helps to understand the operationalization and measurement of PE pointing out the attributes and dimensions that have been considered in several empirical studies on this topic. At this point, the article advances concerning existing reviews (e.g., Beattie et al., 2015; Male et al., 2017) in terms of breadth (total of articles analyzed) and scope (variables analyzed). Second, the identification of the main independent variables (attributes and dimensions of PE) and the dependent variables (PE results) can help in the construction of new acceptable and relevant instruments to measure $\mathrm{PE}$ in the hospital. Finally, the article collaborates by carrying out an analysis of the main quantitative instruments already used, which can be useful for hospital managers and other health professionals interested in evaluating and identifying discrepancies in the health services provided.

\section{Research method}

A scoping review is used to synthesize evidence from a set of studies linked to a study topic to identify gaps in the existing literature. Also, this type of study is recommended to map key concepts that support a particular research topic, especially when it is complex or little-explored (Arksey \& O'Malley, 2005; Peterson et al., 2017). In particular, the use of scope reviews has a wide use and acceptance in studies related to the medical field (Peterson et al., 2017). Thus, it is believed that the scoping review is adequate to explore the theme addressed in this article. For its execution, the steps proposed by Arksey \& O'Malley, (2005) were followed: (i) Identify research questions; (ii) Identify and select relevant studies; (iii) Archive and tabulate the data; and (iv) Grouping, summarizing, and reporting results. 


\subsection{Identify research questions}

PE is not a clearly defined concept, which challenges its accurate measurement (Wolf \& Jason, 2014; Rapport et al., 2019). In this case, research instruments may include constructs that do not accurately get patient responses to cognitive and behavioral stimuli linked to health care (Kashif et al., 2016). Furthermore, the diversity of constructs (independent and dependent) contained in previous studies makes it difficult to choose among the several options for assessing PE (Beattie et al., 2015; Male et al., 2017; Rapport et al., 2019). The lack of clarity regarding what to measure and how to measure PE can intensify the panorama of research related to this theme, contributing to producing a fragmented understanding of the measurement of PE and making comparisons among studies difficult. Therefore, there is a need for studies that can map the literature on PE to identify how it has been measured (instruments used) and organize the independent (antecedents) and dependent (consequent) constructs of PE. In short, based on the exposition of the research problem, relevant questions about the measurement of PE that could guide the investigation were identified. Therefore, this article seeks to answer the following questions:

QP\#1 What are the characteristics of empirical research on PE in hospitals?

QP\#2 What are the main PE assessment instruments cited in the literature?

QP\#3 What are the independent constructs (attributes) considered in measuring PE?

QP\#4 What are the results considered when measuring PE?

The questions were formulated to support the comprehensive review of the literature on the measurement of PE, and their answers were obtained through a robust and documented structure (Arksey \& O'Malley, 2005).

\subsection{Identify and select relevant studies}

A second step refers to the selection of articles that make up the final sample. In this case, the identification and selection procedures were based on Beattie et al. (2015).

Figure 1 illustrates the steps used to carry out this research.

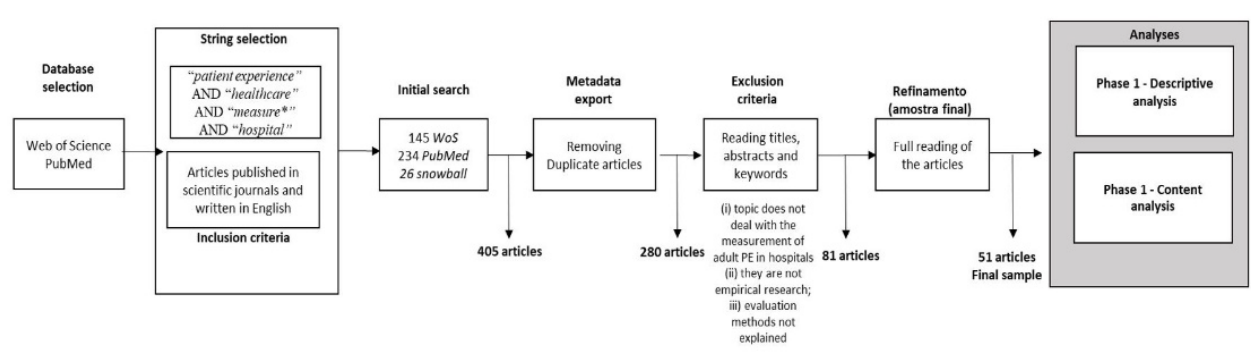

Figure 1. Literature search process 
study. The definition of search terms was inspired by Beattie et al. (2015), however, modifications were made to expand the identification of articles, for example, the exclusion of the terms "inpatients" and "questionnaires", aiming at not limiting the articles that measured PE only in the inpatient sector or that used only questionnaires as assessment tools. Thus, the terms used were: "patient experience" AND "healthcare" AND "measure *" AND "hospital". As inclusion criteria, the following search filters were adopted: English language and timeframe from December 2013 to June 2019. Therefore, a longer period than that was investigated by Beattie et al. (2015), complementing its article base. Based on the procedures described, the search returned 379 articles, 145 from Web of Science and 234 from PubMed Central. 26 articles by Beattie et al. (2015) were included, totaling 405 articles. Metadata for these articles were extracted and exported to Mendeley bibliographic management software. After removing duplicate articles, an initial sample of 280 articles was obtained.

The next steps were the reading of titles, abstracts, and keywords for article selection. In this case, articles were selected that i) addressed the issue of measuring the experience of adult patients in hospitals, ii) presented results of empirical research; iii) whose evaluation method was explained (e.g., type of strategy, instrument, variables, and results, etc.), allowing the identification of the observed variables. Consequently, articles were not selected that i) did not measure PE in health (e.g., Doyle et al., 2013), ii), focused on the assessment of satisfaction (e.g., Malik et al., 2016) or hospital safety (e.g., Lawton et al., 2015) instead of PE, iii), did not address the general hospital (e.g., Caneiras et al., 2019) or iv) or focused on the children's experience (e.g., Toomey et al., 2015). With these criteria, we sought to analyze a more homogeneous sample of studies related to PE (considering the same type of patients, care, and health organization), as also suggested by Beattie et al. (2015). In case of doubt, the articles were read in full for a decision to include or not. Articles that did not provide access to the full text or technical reports were also discarded. Two of the authors engaged in this selection task. After this second filter, the sample had 81 articles. When starting to read the full text of these articles, 30 of them were discarded for not meeting the inclusion criteria. Therefore, the final sample includes 51 focal articles.

\subsection{Filing and tabulating data}

This step aimed to map the main variables that were observed in the publications to create a database that will serve as a source for further analysis (Arksey \& O'Malley, 2005). The articles were organized in a spreadsheet with the following information to support the descriptive analysis: year, journals, type of approach, and research strategies. In the thematic analysis, the data collected were: methods used to measure the PE, attributes that form the PE (independent variables), and the objectives measured by the articles.

\subsection{Grouping, summarizing, and reporting results}

Grouping the data and summarizing it provided important information about the articles. The descriptive analysis provided information about the main characteristics of the sample, helping to solve QP1 and partially responding to QP2. Content analysis (thematic) allowed a quantitative/qualitative examination of the content of the articles 
according to the characteristics of the applied PE measurement methods, answering the QP2, QP3, and QP4. The thematic analysis also helped to report and categorize the challenges and opportunities of measuring PE. These results are presented in the next sections.

\section{Results}

\subsection{Descriptive analysis}

The evolution of scientific production on the subject is represented in Figure 2. There was a greater interest in the subject from 2012, and the year in which there was the greater publication of articles in this research was 2016, with approximately $19.6 \%$ of the articles (e.g., Kemp et al., 2016).

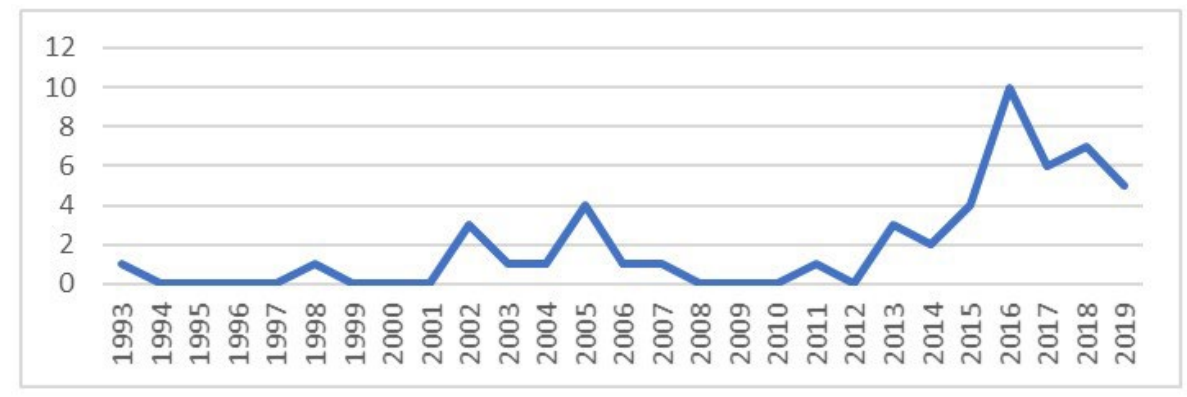

Figure 2. Frequency of publication.

The articles were published in 31 journals. In Table 1, there are journals with two or more publications. BMJ Open has the highest number of published articles (e.g., Beattie et al., 2016; Kemp et al., 2016; Lane et al., 2016), followed by International Journal for Quality in Health Care (e.g., Pettersen et al., 2004; Rao et al., 2006) and by BMC Health Services Research journals (e.g., Brown et al., 2015; Liu et al., 2017; McLean et al., 2017) and Health Services Research (e.g., Levine et al., 2005; O'Malley et al., 2005; Sofaer et al., 2005).

Table 1. Newspapers.

\begin{tabular}{lcc}
\hline \multicolumn{1}{c}{ Newspapers } & Total of articles & $\%$ \\
\hline BMJ Open & 6 & $11.76 \%$ \\
\hline International Journal for Quality in Health Care & 5 & $9.8 \%$ \\
\hline BMC Health Services Research & 4 & $7.84 \%$ \\
\hline Health Services Research & 4 & $7.84 \%$ \\
\hline BMJ Quality \& Safety & 2 & $3.92 \%$ \\
\hline International Journal of Health Care Quality Assurance & 2 & $3.92 \%$ \\
\hline Journal of Hospital Medicine & 2 & $3.92 \%$ \\
\hline Journal of Patient Experience & 2 & $3.92 \%$ \\
\hline Scandinavian Journal of Caring Sciences & 2 & $3.92 \%$ \\
\hline
\end{tabular}


Regarding the research approach, $66.67 \%$ (34 articles) of the articles used the quantitative approach exclusively (e.g., Garrard \& Narayan, 2013; Kerezoudis et al., 2018; Alaloul et al., 2019). The qualitative approach was used exclusively in $11.76 \%$ of the articles (6 articles) only (e.g, Kuis \& Goossensen, 2017; Rapport et al., 2019). However, a qualitative-quantitative approach, which includes both approaches, was adopted in 11 articles (21.57\%) (e.g., Rao et al., 2006; Carter et al., 2018). To complement the characterization of the research methods adopted by the focal articles, Table 2 presents the research strategies used.

Table 2. Research Strategy.

\begin{tabular}{lc}
\hline \multicolumn{1}{c}{ Research Strategy } & Total of articles \\
\hline Survey & 34 \\
\hline Survey + individual interviews & 7 \\
\hline Individual interviews $^{*}$ & 4 \\
\hline Survey + individual interviews + focal groups & 3 \\
\hline Individual interviews + focal groups & 1 \\
\hline Focal groups & 1 \\
\hline Survey + focal groups & 1 \\
\hline Total of articles & $\mathbf{5 1}$ \\
\hline
\end{tabular}

*It includes the instruments "Diary of Patient" and "Emotional Touchpoint" and quantitative instruments as an interview.

The survey was the most used research strategy among the focal articles, with $66.67 \%$ (34) of the articles using only this method. In addition to it, the survey was also applied with other qualitative strategies, with a total of $88.24 \%$ of the articles. This research strategy is more appropriate when the operationalization variables of a construct are already consolidated, although this is not the case for PE. However, PE follows a trend of quantitative analysis adopted in the areas of satisfaction and quality in services. Although qualitative strategies ensure a deeper understanding of PE, studies that relied only on this type of strategy were less observed. Only interviews were used by only $7.84 \%$ of the articles. However, they were based on constructs present in instruments such as HCAHPS and Quality form the Patient's Perspective - QPP (Levine et al., 2005; Wilde et al., 1993) or instruments such as the "Diary of patient" (Webster et al., 2019) and the "Emotional Touchpoint" (Kuis \& Goossensen, 2017). The interview strategy, when considering all the articles in which it was applied, was observed in $29.41 \%$ of the sample.

\subsection{Thematic analysis}

\subsubsection{Instruments for measuring patient experience}

Table 3 shows PE assessment instruments identified in the articles. "Hospital Consumer Assessment of Healthcare Providers and Systems" (HCAHPS) was the most mentioned method in the articles (39.22\%). This instrument consists of 29 items, with attributes such as communication with physicians, communication with nurses, the responsiveness of the hospital staff, communication about medications, information about discharge and transition of care/care, cleanliness and tranquility of the hospital 
environment, a general classification of the hospital and possibility of recommendation. The pain control variable was eliminated from surveys of patients who were discharged as of October 1, 2019, by the Centers for Medicare and Medicaid Services (AHRQ, 2018). HCAHPS is highly popular among American hospitals, as an indicator of hospital quality by health management organizations such as the Medicare and Medicaid Service Centers (Giordano et. al., 2010; Rodrigues, 2019).

Table 3. Measurement Instruments of the patient's experience.

\begin{tabular}{|c|c|c|}
\hline Evaluation Instrument & Articles & Total \\
\hline $\begin{array}{l}\text { HCAHPS (Hospital Consumer Assessment of Healthcare } \\
\text { Providers and Systems) }\end{array}$ & $\begin{array}{l}1,2,6,7,8,9,11,14 \\
21,22,23,30,34,36 \\
39,40,41,44,46,48\end{array}$ & 20 \\
\hline $\begin{array}{l}\text { PPE - } 15 \text { or PPE - 33(Picker Patient Experience } \\
\text { Questionnaire) }\end{array}$ & $16,17,32,37,43$ & 5 \\
\hline QPP (Quality of care from the patient's Perspective) & $27,28,50$ & 3 \\
\hline HKIEQ (Hong Kong Inpatient Experience Questionnaire) & 10,51 & 2 \\
\hline $\begin{array}{l}\text { PEECH (Patient Evaluation of Emotional Care during } \\
\text { Hospitalisation) }\end{array}$ & 35,37 & 2 \\
\hline PPQ (Patient Perceptions of Quality) & 4,24 & 2 \\
\hline Press Ganey & 15,42 & 2 \\
\hline Own Questionnaire & 33,26 & 2 \\
\hline $\begin{array}{l}\text { CCAENA (Questionnaire of Continuity between Care } \\
\text { Levels) }\end{array}$ & 31 & 1 \\
\hline CEFIT (Care Experience Feedback Improvement Tool) & 3 & 1 \\
\hline $\begin{array}{l}\text { CEPS IC (Canadian Patient Experience Survey-Inpatient } \\
\text { Care) }\end{array}$ & 45 & 1 \\
\hline CollaboRATE & 12 & 1 \\
\hline Diary of patient (escrito pelo próprio paciente) & 49 & 1 \\
\hline Emotional Touchpoint & 25 & 1 \\
\hline EUROPEP Questionnaire & 47 & 1 \\
\hline EXQ (Customer Experience Quality) & 20 & 1 \\
\hline FPS (Flemish Patient Survey) & 5 & 1 \\
\hline $\begin{array}{l}\text { I-PAHC (Patient Assessment of Healthcare for Inpatient } \\
\text { Care) }\end{array}$ & 29 & 1 \\
\hline JPCAT (Primary Care Assessment Tool) & 19 & 1 \\
\hline NORPEQ (Norwegian patient experience questionnaire) & 38 & 1 \\
\hline $\begin{array}{l}\text { O-PAHC (Patient Assessment of Healthcare for Outpatient } \\
\text { Care) }\end{array}$ & 29 & 1 \\
\hline PEQ (Patient Experience Questionnaire) & 18 & 1 \\
\hline SERVQUAL & 13 & 1 \\
\hline
\end{tabular}

Subtitle: 1. (Alaloul et al., 2019); 2. (Banka et al., 2015); 3. (Beattie et al., 2016); 4. (Brown et al., 2015); 5. (Bruyneel et al., 2017); 6. (Carter et al., 2018); 7. (Chan et al., 2015); 8. (Cowen et al., 2016); 9. (Drennan et al., 2018); 10. (Wong et al., 2013); 11. (Fisher et al., 2019); 12. (Forcino et al., 2018); 13. (Garrard \& Narayan, 2013); 14. (Gillam et al., 2016); 15. (Heyworth et al., 2014); 16. (Jenkinson et al., 2002); 17. (Jenkinson et al., 2003); 18. (Pettersen et al., 2004); 19. (Kaneko et al., 2019); 20. (Kashif et al., 2016); 21 (Keller et al., 2005); 22. (Kemp et al., 2016); 23. (Kerezoudis et al., 2018); 24. (Rao et al., 2006); 25. (Kuis \& Goossensen, 2017); 26. (Lane et al., 2016); 27. (Larsson et al., 1998); 28. (Larsson \& Larsson, 2002); 29. (Lawton et al., 2015); 30. (Levine et al., 2005); 31. (Liu et al., 2017); 32. (Lusilla-Palacios \& CastellanoTejedor, 2017); 33. (Malik et al., 2016); 34. (McFarlan et al., 2019); 35. (McLean et al., 2017); 36. (Merlino et al., 2014); 37. (Murrells et al., 2013); 38. (Oltedal et al., 2007); 39. (O'Malley et al., 2005); 40. (Otani et al., 2016); 41. (Pottenger et al., 2016); 42. (Rapport et al., 2019); 43. (Reeves et al., 2002); 44 (Roseen et al., 2017); 45. (Rubens et al., 2018); 46. (Sofaer et al., 2005); 47. (Van den Hombergh et al., 2016); 48. (Wallace et al., 2018); 49. (Webster et al., 2019); 50. (Wilde et al., 1993); 51. (Wong et al., 2015). 
The second most used instrument $(9.80 \%)$ was Picker Patient Experience Questionnaire (PPE). It was originally elaborated with 15 items by Reeves et al. (2002), but an expanded version with 33 items was used by Lusilla-Palacios \& CastellanoTejedor (2017). The questionnaire addresses the variables: information and education, care coordination, physical comfort, emotional support, respect for the patient's request, involvement of family and friends, continuity and transition, and overall impression (Lusilla-Palacios \& Castellano-Tejedor, 2017). Next, there is Quality of care from the Patient's Perspective (PPQ), with 5.88\%, which was developed by Wilde et al. (1993) to capture quality from the patient's perspective. Larsson et al. (1998) formulated the version of the questionnaire with 68 items, reduced to 24 items by Larsson \& Larsson (2002). QPP addresses the variables: physician's technical competence, commitment, technical and physical conditions, characteristics and situation of the place, socio-cultural atmosphere, identity-oriented approach, patient participation, meeting personal needs, and positive treatment of significant people (Wilde et el., 1993; Larsson \& Larsson, 2002). The 24-item version addresses the variables: physician's technical competence, technical and physical conditions, sociocultural atmosphere, and identity-oriented approach (Larsson \& Larsson, 2002). Both HCAHPS, PPE, and QPP assess different aspects of the hospital experience, with many dimensions of service quality.

In addition to these, there are less-used instruments, such as Emotional Touchpoint and Customer Experience Quality (EXQ). Emotional Touchpoint is an instrument in which no predefined category is used, based solely on the patients' values, being essential from the ethical point of view of care (Kuis \& Goossensen, 2017). The instrument assesses touchpoints, which characterize the main moments in which the patient remembers having been touched emotionally or cognitively (Kuis \& Goossensen, 2017). EXQ instrument consists of a scale made by four dimensions: product experience, focus on results, moments of truth, and peace of mind (Maklan, 2012). Through the 19-item scale, it was concluded that the service experience has a considerable influence on customer satisfaction, loyalty, and indication (Maklan, 2012). Kashif et al. (2016) adapted the scale to measure constructs related to PE in Malaysian hospitals.

\subsubsection{Attributes (independent variables)}

Table 4 presents the individual variables (attributes) considered by the authors to measure PE. They were identified from the content analysis of the assessment instruments. In all, 98 individual variables were identified. Later, they were grouped into categories (constructs/dimensions) according to their similar nature. Table 4 presents this grouping.

Table 4. Categories and Independent Variables.

\begin{tabular}{|c|c|c|}
\hline Constructs/Independent Variables & Articles & Total \\
\hline \multicolumn{3}{|c|}{ Admission and Accessibility } \\
\hline System access & 3 & \\
\hline Improved access to care & 15 & \\
\hline Immediate access & 10 & 6 \\
\hline Admission & 45,51 & \\
\hline First contact & 19 & \\
\hline
\end{tabular}


Table 4. Continued...

\begin{tabular}{|c|c|c|}
\hline Constructs/Independent Variables & Articles & Total \\
\hline \multicolumn{3}{|c|}{ Hospital Discharge and Care Transition } \\
\hline $\begin{array}{l}\text { Information on hospital discharge and transition of care } \\
\text { and care }\end{array}$ & $\begin{array}{c}1,9,22,23,41,45,46 \\
48,51\end{array}$ & \multirow{5}{*}{19} \\
\hline Continuity and Transition & $16,32,43$ & \\
\hline Relational, informational, and managerial continuity & 31 & \\
\hline Discharge information & $\begin{array}{c}1,2,7,8,21,22,23 \\
39,41,48\end{array}$ & \\
\hline Preparation for discharge & 42 & \\
\hline \multicolumn{2}{|l|}{ Hospital Environment } & \\
\hline Food & 51 & \multirow{8}{*}{18} \\
\hline Healing environment & 33 & \\
\hline Sociocultural atmosphere & $27,28,50$ & \\
\hline Physical comfort & $16,32,43$ & \\
\hline Visit coordination and quality & 15 & \\
\hline Tranquility and Cleanliness & $1,2,22,23,46,48$ & \\
\hline Organization & 18 & \\
\hline Privacy & 5,10 & \\
\hline \multicolumn{2}{|l|}{ Communication and Information } & \multirow{14}{*}{29} \\
\hline Ability to transmit information & 13 & \\
\hline Communication with nurses & $\begin{array}{c}1,2,7,8,9,11,21,22 \\
23,29,36,39,40,45 \\
46,48\end{array}$ & \\
\hline Communication with doctors & $\begin{array}{c}1,2,9,11,15,21,22 \\
23,29,39,40,45,46 \\
48\end{array}$ & \\
\hline General communication & 18,42 & \\
\hline Communication about medications & $\begin{array}{c}1,2,7,8,9,14,18,21 \\
22,23,29,39,46,48\end{array}$ & \\
\hline Provision of information & 10 & \\
\hline Information & $16,32,43$ & \\
\hline information and communication & 5 & \\
\hline Information about exams/tests & 18,38 & \\
\hline Information about future complaints & 18 & \\
\hline Guidance & 15,19 & \\
\hline Perception of being informed & 12 & \\
\hline Responding to Concerns and Complaints & 42 & \\
\hline \multicolumn{2}{|l|}{ Care and Safety } & \multirow{11}{*}{24} \\
\hline Pain control & $\begin{array}{c}1,2,5,8,9,21,22,23 \\
29,36,39,44,46,48\end{array}$ & \\
\hline Care coordination & $10,16,32,43$ & \\
\hline Beware at the right time & 3 & \\
\hline Care and treatment & 51 & \\
\hline Safe care & 5 & \\
\hline Best and worst aspects of care & 26 & \\
\hline Care orientation & 15 & \\
\hline Care plan & 33 & \\
\hline Quality of care & 10 & \\
\hline Safety & $3,33,37$ & \\
\hline
\end{tabular}


Table 4. Continued...

\begin{tabular}{|c|c|c|}
\hline Constructs/Independent Variables & Articles & Total \\
\hline \multicolumn{2}{|l|}{ Hospital Team } & \\
\hline Heads up & 3 & \multirow{20}{*}{26} \\
\hline General service/team support & 10,15 & \\
\hline Ability to develop the service reliably and accurately & 13 & \\
\hline Responsiveness & $\begin{array}{c}1,2,8,21,22,23,36 \\
39,40,45,46,48\end{array}$ & \\
\hline Commitment & 27,50 & \\
\hline Connection with the team & 37,44 & \\
\hline Reliability & 13 & \\
\hline Knowledge & 13,37 & \\
\hline Coordination & 5,19 & \\
\hline Courtesy & 13 & \\
\hline Disposition & 13 & \\
\hline Education & $16,32,43$ & \\
\hline Empathy & 13 & \\
\hline Identification with patients & 34 & \\
\hline Precision & 13 & \\
\hline Speed & 13 & \\
\hline Respect & $5,10,16,32,43$ & \\
\hline Sensitivity & 13 & \\
\hline Emotional support & $16,32,43$ & \\
\hline Teamwork & 15,34 & \\
\hline \multicolumn{2}{|l|}{ Experience } & \multirow{5}{*}{8} \\
\hline Experience with the product (service) & 20 & \\
\hline General experience at the hospital & 26,44 & \\
\hline Overall impression & $16,32,43,51$ & \\
\hline General satisfaction & 18 & \\
\hline \multicolumn{2}{|l|}{ Infrastructure } & \\
\hline Technical and physical conditions & $27,28,50$ & \multirow{7}{*}{11} \\
\hline Hospital and equipment & 13,18 & \\
\hline Infrastructure & 24 & \\
\hline Facilities, characteristics, and location situation & $10,13,27,50,51$ & \\
\hline Communication materials & 13 & \\
\hline Management practices & 47 & \\
\hline Available services & 19 & \\
\hline \multicolumn{2}{|l|}{ Quality and Services } & \\
\hline Medical assistance/services & 4,18 & \\
\hline Nursing care/services & 4,18 & 13 \\
\hline Hospital general classification & \multicolumn{2}{|c|}{$8,11,34,36,41,44$} \\
\hline Physician's technical competence & $27,28,50$ & \\
\hline General perception of quality & 4 & \\
\hline Room quality & 40 & \\
\hline General Quality / Quality & 33 & \\
\hline \multicolumn{2}{|l|}{ Feelings and Behaviors } & \\
\hline Emotion or cognition & 25 & \multirow{2}{*}{8} \\
\hline Moments of truth & 20 & \\
\hline
\end{tabular}


Table 4. Continued...

\begin{tabular}{|c|c|c|}
\hline Constructs/Independent Variables & Articles & Total \\
\hline Peace of mind & 20 & \\
\hline Possibility of recommendation & $11,34,36,44$ & \\
\hline Personal value & 35,37 & \\
\hline \multicolumn{3}{|l|}{ Treatment } \\
\hline Functional and transactional aspects of treatment & 37 & \multirow{4}{*}{4} \\
\hline Availability of medications & 24 & \\
\hline Efficiency & 3 & \\
\hline Focus on the result & 20 & \\
\hline \multicolumn{3}{|l|}{ Dealing with the Patient and Family } \\
\hline Identity-oriented approach & $27,28,50$ & \multirow{9}{*}{13} \\
\hline Person-centered service/individualized care & $13,33,45$ & \\
\hline Dignity of the patient & 33 & \\
\hline $\begin{array}{l}\text { Involvement, contact and positive treatment of } \\
\text { significant people, family, and friends }\end{array}$ & $16,27,32,42,43,50$ & \\
\hline $\begin{array}{l}\text { Involvement/participation of the patient in the } \\
\text { decision/treatment }\end{array}$ & $10,12,27,42,50$ & \\
\hline Emotional and Spiritual Needs & 42 & \\
\hline Physical and personal needs & $10,27,50$ & \\
\hline Preparation for hospital admission & 5 & \\
\hline Treatment of patient's feedback & 10 & \\
\hline
\end{tabular}

Subtitle: 1. (Alaloul et al., 2019); 2. (Banka et al., 2015); 3. (Beattie et al., 2016); 4. (Brown et al., 2015); 5. (Bruyneel et al., 2017); 7. (Chan et al., 2015); 8. (Cowen et al., 2016); 9. (Drennan et al., 2018); 10. (Wong et al., 2013); 11. (Fisher et al., 2019); 12. (Forcino et al., 2018); 13. (Garrard \& Narayan, 2013); 14. (Gillam et al., 2016); 15. (Heyworth et al., 2014); 16. (Jenkinson et al., 2002); 18. (Pettersen et al., 2004); 19. (Kaneko et al., 2019); 20. (Kashif et al., 2016); 21. (Keller et al., 2005); 22. (Kemp et al., 2016); 23. (Kerezoudis et al., 2018); 24. (Rao et al., 2006); 25. (Kuis \& Goossensen, 2017); 26. (Lane et al., 2016); 27. (Larsson et al., 1998); 28. (Larsson \& Larsson, 2002); 29. (Lawton et al., 2015); 31. (Liu et al., 2017 ); 32. (Lusilla-Palacios \& Castellano-Tejedor, 2017); 33. (Malik et al., 2016); 34. (McFarlan et al., 2019); 35. (McLean et al., 2017); 36. (Merlino et al., 2014); 37. (Murrells et al., 2013); 38. (Oltedal et al., 2007); 39. (O'Malley et al., 2005); 40. (Otani et al., 2016); 41. (Pottenger et al., 2016); 42. (Rapport et al., 2019); 43. (Reeves et al., 2002); 44. (Roseen et al., 2017); 45. (Rubens et al., 2018); 46. (Sofaer et al., 2005); 47. (Van den Hombergh et al., 2016); 48. (Wallace et al., 2018); 50. (Wilde et al., 1993); 51. (Wong et al., 2015).

The most frequent dimensions are Communication and Information, that is, $56.9 \%$ of the articles had one or more individual variables about them. A concern with the work team is also evident through variables that identify competence, responsibility, empathy, knowledge, and others. Therefore, the Hospital Team category focuses on the quality of the health professional and was addressed in $50.98 \%$ of the articles. Finally, Care and Safety, evidenced in $47 \%$ of the articles in the sample, shows that there is a concern with aspects such as care at the right time, coordination, and guidance of care and safety. On the other hand, two categories were less addressed: Treatment (7.84\%) and Admission and Accessibility (11.76\%). The fact that the category Treatment is less addressed maybe, hypothetically, due to the understanding that patients do not have the clinical knowledge to assess the effectiveness of the treatment, being the entire responsibility of physicians and nurses. The variables in the Admission and Accessibility category were considered by the formulators of the instruments as less important because they understood that they may already be incorporated in other aspects that are evaluated.

Regarding individual variables, the most cited were: communication with nurses $(31.37 \%)$, communication with doctors $(27.45 \%)$, communication about medication $(27.45 \%)$, pain control $(27.45 \%)$, and responsiveness of the team $(23.53 \%)$. It is noticed 
that communication is seen with great importance not only as a category but also through its variables. The variables pain control and team responsiveness comprise, respectively, the Care and Safety and Hospital Team categories, which are also among the most evident.

\subsubsection{PE results}

Table 5 identifies the main results of the experiment (dependent variables) in the sample articles. These variables were also grouped, by similarity, into outcome categories (constructs). Of the focal articles, 10 of them (e.g., Levine et al., 2005; O'Malley et al., 2005; McLean et al., 2017) focused on developing, testing, or reducing the instruments, not emphasizing a specific result. The Experience category is represented in the variables patient-centered care experience, the experience of care continuity, patient experience, and patient experience with the nursing team, having been the most used $(62.75 \%$ of the articles), which indicates a consolidation of this measure about "patient experience" in the health area. It is possible to observe that the patient experience result was found in $41.18 \%$ of the articles. Also, according to Table 5 , although the articles focus on measuring PE, constructs such as satisfaction and service quality are also present in the literature. For example, results related to satisfaction are present in $19.61 \%$ and service quality in $9.80 \%$ of the articles in the sample. It is interesting to notice that customer satisfaction, loyalty and indication are traditional results of service quality (Verhoef et al., 2002), but that they have also been used as results of customer experience (Klaus \& Maklan, 2013). However, the use of loyalty and indication objectives is still incipient in the measurement of PE in hospitals.

Table 5. Experience Results.

\begin{tabular}{|c|c|c|}
\hline Categories/ Variables & Articles & Total \\
\hline \multicolumn{3}{|l|}{ Experience } \\
\hline Patient-centered care experience & 15 & \multirow{4}{*}{24} \\
\hline Continuity of Care Experience & 31 & \\
\hline Patient's experience & $\begin{array}{c}3,5,6,7,8,10,16,18,19,23,26,29 \\
34,37,38,41,42,44,47,49,51\end{array}$ & \\
\hline Patient's experience with the nursing team & 9 & \\
\hline \multicolumn{3}{|l|}{ Satisfaction } \\
\hline Satisfaction & $1,2,20,24,32,33,36,40,42$ & \multirow{2}{*}{9} \\
\hline Satisfaction with medical care & 2 & \\
\hline \multicolumn{3}{|l|}{ Quality } \\
\hline $\begin{array}{l}\text { General classification of physician and } \\
\text { ward }\end{array}$ & 22 & \multirow{4}{*}{5} \\
\hline Patient's expectations & 13 & \\
\hline Quality from the patient's perspective & 28,50 & \\
\hline Perceived quality & 4 & \\
\hline \multicolumn{3}{|l|}{ Communication } \\
\hline Indication & 20 & \multirow{3}{*}{3} \\
\hline Communication about medications & 14 & \\
\hline $\begin{array}{l}\text { Comfort to talk about problems during } \\
\text { hospitalization }\end{array}$ & 11 & \\
\hline Loyalty & & \\
\hline
\end{tabular}


Table 5. Continued...

\begin{tabular}{lcc}
\hline \multicolumn{1}{c}{ Categories/ Variables } & Articles & Total \\
\hline Loyalty & 20 & 2 \\
\hline Recommendation & 2 & \\
\hline Caution & & 2 \\
\hline General care & 45 & 2 \\
\hline Ethics of care & 25 & \\
\hline
\end{tabular}

Subtitle: 1. (Alaloul et al., 2019); 2. (Banka et al., 2015); 3. (Beattie et al., 2016); 4. (Brown et al., 2015); 5. (Bruyneel et al., 2017); 6. (Carter et al., 2018); 7. (Chan et al., 2015); 8. (Cowen et al., 2016); 9. (Drennan et al., 2018); 10. (Wong et al., 2013); 11. (Fisher et al., 2019); 13. (Garrard \& Narayan, 2013); 14. (Gillam et al., 2016); 15. (Heyworth et al., 2014); 16. (Jenkinson et al., 2002); 18. (Pettersen et al., 2004); 19. (Kaneko et al., 2019); 20. (Kashif et al., 2016); 22. (Kemp et al., 2016); 23. (Kerezoudis et al., 2018); 24. (Rao et al., 2006); 25. (Kuis \& Goossensen, 2017); 26. (Lane et al., 2016); 28. (Larsson \& Larsson, 2002); 29. (Lawton et al., 2015); 31. (Liu et al., 2017); 32. (Lusilla-Palacios \& Castellano-Tejedor, 2017); 33. (Malik et al., 2016); 34. (McFarlan et al., 2019); 36. (Merlino et al., 2014); 37. (Murrells et al., 2013); 38. (Oltedal et al., 2007); 40. (Otani et al., 2016); 41. (Pottenger et al., 2016); 42. (Rapport et al., 2019); 44. (Roseen et al., 2017); 45. (Rubens et al., 2018); 47. (Van den Hombergh et al., 2016); 49. (Webster et al., 2019); 50. (Wilde et al., 1993); 51. (Wong et al., 2015).

\section{Discussion}

Some discussion points are highlighted from the results. First, concerning the research methods, most research on measuring PE is based on traditional methods such as quantitative research and survey application (Silva et al., 2018). Our results show that this strategy has a long tradition in the evaluation of related constructs (e.g., service quality, satisfaction, etc.). Despite providing structured results and reaching a larger number of patients, the quantitative approach is limited to the variables analyzed. Therefore, it is interesting to complement the PE assessment with qualitative methods. In general, qualitative methods that use strategies, such as interviews and focus groups, are also used and allow us to achieve this objective. Thus, the association of qualitative and quantitative methods favors a greater capture of $\mathrm{PE}$, enabling the crossvalidation of qualitative and quantitative data to observe converging points and obtain greater depth on PE (LaVela \& Gallan, 2014).

The second point of discussion refers to the most used assessment instrument. A stream of research was observed that proposed assessment instruments for this purpose, such as HCAHPS (O'Malley et al., 2005), PPE (Reeves et al., 2002), QPP (Larsson et al., 1998), and other less frequent instruments, as shown in Table 3 . This diversity of measuring instruments occurs because there is no consensus on the PE concept and its formative dimensions (Ahmed et al., 2014). Furthermore, many dimensions related to service quality and satisfaction are generally considered formative of PE, as well as complementing its metrics. However, although there is no consensus on the best method for measuring it, there is a trend towards greater use of the HCAHPS instrument. It is believed that this trend is due to the instrument is originally American, where the government payment to these providers is related to $\mathrm{PE}$ measurement through the HCAHPS method and the results of this measurement are publicly disclosed (Rodrigues, 2019). Thus, health institutions felt obliged to be concerned about PE, as it began to affect the financial part and the image of health institutions in the country (Rodrigues, 2019).

A third point refers to the categories and individual variables considered in the different PE assessment instruments. Table 6 shows the independent variables and the respective categories that make up the instruments most used in the sample. It is possible to notice that HCAHPS variables have greater evidence than other 
instruments and the variables that have been considered with greater weight by the most evidenced instruments are focused on relational issues involving the patient and the team providing the service. Suggestions for the implementation of training strategies (Alástico \& Toledo, 2013), educational, emotional, and cultural (Wiig et al., 2013) were found in the literature to contribute to the quality of hospital services and the recognition and appreciation of the involvement and experiences of patients by staff. The fact that nursing teams are close to patients and in constant contact with other professionals has an impact on the establishment of hospital accreditation (Mendes \& Mirandola 2015), which directly influences quality and PE. For this reason, Leggat et al. (2017) emphasize the importance of training for better development of team functions

Table 6. Independent Variables and Assessment Instruments.

\begin{tabular}{|c|c|c|c|c|c|}
\hline Independent Variables & Category & $\%$ & HCAHPS & PPE & QPP \\
\hline Communication with nurses & $\begin{array}{l}\text { Communication and } \\
\text { Information }\end{array}$ & $31.37 \%$ & $x$ & & \\
\hline Communication with doctors & $\begin{array}{l}\text { Communication and } \\
\text { Information }\end{array}$ & $27.45 \%$ & $\mathrm{x}$ & & \\
\hline Communication about medicines & $\begin{array}{l}\text { Communication and } \\
\text { Information }\end{array}$ & $27.45 \%$ & $x$ & & \\
\hline Pain control & Care and Safety & $27.45 \%$ & $x$ & & \\
\hline Team Responsiveness & Hospital Team & $23.53 \%$ & $x$ & & \\
\hline $\begin{array}{l}\text { Information on discharge and } \\
\text { transition of care/attendance }\end{array}$ & $\begin{array}{l}\text { Hospital Discharge and } \\
\text { Care Transition }\end{array}$ & $19.60 \%$ & $\mathrm{X}$ & & \\
\hline Hospital general classification & Quality and Services & $11.76 \%$ & $\mathrm{X}$ & & \\
\hline $\begin{array}{l}\text { Involvement, contact and positive } \\
\text { treatment of significant people, } \\
\text { family and, friends }\end{array}$ & $\begin{array}{l}\text { Dealing with the Patient } \\
\text { and Family }\end{array}$ & $11.76 \%$ & & & $x$ \\
\hline $\begin{array}{l}\text { Tranquility and Cleanliness of the } \\
\text { Hospital Environment }\end{array}$ & Hospital Environment & $11.76 \%$ & $x$ & & \\
\hline $\begin{array}{l}\text { Involvement/participation of the } \\
\text { patient in the decision/treatment }\end{array}$ & $\begin{array}{l}\text { Dealing with the Patient } \\
\text { and Family }\end{array}$ & $9.80 \%$ & & $x$ & $x$ \\
\hline $\begin{array}{l}\text { Facilities, characteristics and, } \\
\text { location situation }\end{array}$ & Infrastructure & $9.80 \%$ & & & $\mathrm{X}$ \\
\hline Respect for the patient's request & Hospital Team & $9.80 \%$ & & $x$ & \\
\hline Care coordination & Care and Safety & $7.84 \%$ & & $X$ & \\
\hline Overall impression & Experience & $7.84 \%$ & & $x$ & \\
\hline Possibility of recommendation & Feelings and Behaviors & $7.84 \%$ & $x$ & & \\
\hline Identity-oriented approach & $\begin{array}{l}\text { Dealing with the Patient } \\
\text { and Family }\end{array}$ & $5.88 \%$ & & & $x$ \\
\hline Sociocultural atmosphere & Hospital Environment & $5.88 \%$ & & & $\mathrm{X}$ \\
\hline Physician's technical competence & Quality and Services & $5.88 \%$ & & & $x$ \\
\hline Technical and physical conditions & Infrastructure & $5.88 \%$ & & & $x$ \\
\hline Physical comfort & Hospital Environment & $5.88 \%$ & & $x$ & \\
\hline Continuity and Transition & $\begin{array}{l}\text { Hospital Discharge and } \\
\text { Care Transition }\end{array}$ & $5.88 \%$ & & $x$ & \\
\hline
\end{tabular}


Table 6. Continued...

\begin{tabular}{llccc}
\hline \multicolumn{1}{c}{ Independent Variables } & \multicolumn{1}{c}{ Category } & $\%$ & HCAHPS PPE & QPP \\
\hline Information and education & $\begin{array}{l}\text { Communication and } \\
\text { Information/Hospital } \\
\text { Staff* }\end{array}$ & $5.88 \%$ & X & \\
\hline Physical and personal needs & $\begin{array}{l}\text { Dealing with the Patient } \\
\text { and Family }\end{array}$ & $5.88 \%$ & $\mathrm{X}$ \\
\hline Emotional support & Hospital Team & $5.88 \%$ & $\mathrm{X}$ & $\mathrm{X}$ \\
\hline Commitment & Hospital Team & $3.92 \%$ & \\
\hline
\end{tabular}

*The variable Information belongs to the category Communication and Information and the variable Education belongs to the category Hospital Staff.

Finally, some constructs considered in PE assessment are similar to service quality assessment models (Garrard \& Narayan, 2013). SERVQUAL, for example, was created by Parasuraman et al. (1988) and the constructs evaluated in this model are tangible (physical facilities, equipment, personnel, and communication materials); reliability (the ability of teams to perform the promised service reliably and accurately); guarantee (staff's willingness to help patients, meet their needs, and provide quick service); responsiveness (knowledge and courtesy of the team and their ability to convey information and trust) and empathy (care, sensitivity and individualized attention that the team provides to patients). Thus, when analyzing the SERVQUAL scale's constructs, it is possible to notice similarities when comparing some constructs evidenced in this scoping review (Table 6).

\section{Conclusions}

Measuring PE is one of the challenges for organizations in the healthcare sector. Thus, this article is based on a scoping review to investigate the measurement of PE in hospitals through a sample of 51 empirical articles on the subject. The results show the predominance of quantitative methods (especially the survey method) for measuring PE. Among the instruments used to assess PE, HCAHPS is the most used in focal articles compared to other instruments (e.g., PPE and QPP), because HCAHPS includes a greater number of attributes that contribute to PE. Finally, it was possible to identify the attributes and dimensions (independent variables) considered in the PE assessment. In this case, the relational aspects between patients and health professionals have received great attention in the measurement of PE. Likewise, measures such as patient experience, satisfaction, quality, and loyalty have been used as outcomes (dependent variables) of PE measurement. Theoretical and managerial contributions are highlighted in the next section.

\subsection{Theoretical contributions}

This article has theoretical contributions. First, it contributes to a better understanding of PE measurement identifying the main methods, variables, and constructs used to assess PE in hospitals. This is an important contribution since PE measurement is characterized by literature fragmentation and the use of a wide variety of scales and constructs. Thus, the study adds to other existing reviews (e.g., Beattie et al., 2015; Male et al., 2017) and allows researchers, especially, but not only novices, to better understand PE scope. 
Second, the article also contributes by demonstrating that PE is a construct used to measure patients' sensory, affective, cognitive, relational, and behavioral responses to medical care (Wolf \& Jason, 2014; Rapport et al., 2019). However, the results show (see Table 6) that constructs related to emotional aspects (patient-centered) have been less explored, while constructs related to cognitive and relational aspects are more considered in the studies. However, the patient's emotions directly impact PE and can act as a filter in the relationship between stimuli related to care. Thus, the results of the article can be used for different types of abductive investigations. For example, researchers are encouraged from these results to investigate how patients' positive and negative emotions (e.g., fear, faith, safety, friendship, and respect) affect their perceptions of the experience during the hospital journey.

Finally, our results may support the development of new PE assessment model instruments by pointing out the main methods, variables, and constructs used to assess the experience of adult patients in hospitals. So, researchers can consider the importance of each dimension, depending on the research purpose. However, it is noteworthy that PE is a personal phenomenon with different levels of involvement: rational, emotional, sensory, physical, and spiritual (Wolf \& Jason, 2014; Beattie et al., 2015; Silva et al., 2021).

\subsection{Management contributions}

This paper has two main managerial contributions. First, the article analyzes the main quantitative instruments used to assess the experience of adult patients, which can be useful for hospital managers and health professionals interested in evaluating and identifying discrepancies in the health services provided. In addition to it, these professionals can use instruments that have high acceptance (such as HCAHPS), which will allow them to carry out performance comparisons between their health organizations and others that use the same instrument. Finally, hospital managers and health professionals can rely on the results indicated to create their measuring instruments, as a more efficient diagnosis also contributes to a more assertive design to achieve and sustain loyalty long-term patient care, and the quality of the health service.

\subsection{Limitations and directions for future research}

This article has limitations that point to possibilities for future research. First, other databases can be consulted to expand the search for studies related to this topic. Second, because the delimitation of a research area (experience of adult patients in hospitals) was important to optimize the work; however, other healthcare organizations and other types of patients could have been investigated. Third, the number of empirical studies on PE and the period covered in this research (publications until 2019) are limitations but represent opportunities for further research and updates.

Finally, below, it is shown how the results can contribute to generating new directions for future research. The proposed research agenda is based on the discussions presented as well as the analysis of the articles in the sample. Thus, four main directions for future research are presented below:

- Although there have been advances in PE measurement, new metrics are needed to assess new aspects and new ways of capturing PE (Bull, 2021; Wolf \& Jason, 
2019). This requires that standardized instruments (e.g., HCAHPS, PPE, or QPP) are updated. Thus, future research should consider that PE is dynamic and test new metrics in updating and validating measurement instruments (Bull, 2021; Wolf \& Jason, 2019);

- About patients' emotions, researchers recognize the challenge of adequately capturing patients' emotions about the care they receive throughout their journey with healthcare professionals and organizations (Kashif et al., 2016; Fisher et al., 2019; Silva et al., 2021). Therefore, more research is needed to investigate methods and techniques to assess a patient's emotions.

Several measurement instruments have been created to investigate PE in specific contexts. One example is the predominance of HCAHPS use in the United States (AHRQ, 2018). Thus, future research should test the assessment instruments in different countries or in national health systems to identify cultural differences in perceptions of PE (Beattie et al., 2015; Kashif et al., 2016; Rapport et al., 2019). This research direction is also valid for adapting scales to other specific contexts (e.g., types of patients, the severity of hospital care, etc.). Such initiatives would guarantee the robustness or not of the existing instruments.

Finally, new technologies (e.g., smartphones, telemedicine, artificial intelligence, wearables, etc.) have an impact on PE as well as on the way healthcare organizations offer their services (Webster et al., 2019; Wolf \& Jason, 2019; Silva et al., 2021). For example, the Covid-19 pandemic accelerated the use of technology in healthcare services. Therefore, future research must deal with the impacts of new technologies on PE. For example, new studies should include experiences partially or fully mediated by digital and intelligent technologies (Webster et al., 2019; Wolf \& Jason, 2019).

\section{Author's Contributions}

Juliana Maria Savio Bernardo and Glauco Henrique de Sousa Mendes contribute to the conceptualization and theoretical-methodological approach. The theoretical review was conducted by Juliana Maria Savio Bernardo. Data collection was coordinated by Juliana Maria Savio Bernardo, and Glauco Henrique de Sousa Mendes. Data analysis included Juliana Maria Savio Bernardo, Glauco Henrique de Sousa Mendes, Fabiana Letícia Lizarelli e Meliza Goi Rosconi. All authors worked together in the writing and final revision of the manuscript.

\section{References}

Agency for Healthcare Research and Quality - AHRQ. (2018). Updates to all documents pertaining to april 2018 Public report and the pain management composite. Retrieved in 2018, June 15, from https://hcahpsonline.org/en/whats-new/\#PainMgmtComposite

Ahmed, F., Burt, J., \& Roland, M. (2014). Measuring patient experience: concepts and methods. The Patient-Patient-Centered Outcomes Research, 7(3), 235-241. http://dx.doi.org/10.1007/s40271-014-0060-5. PMid:24831941.

Alaloul, F., Myers, J., Masterson, K. M., DiCicco, J., Perry Collins, M., Hogan, F., Roesler, L., \& Logsdon, M. C. (2019). Patient experience factors and health-related quality of life in hospitalized individuals. Oncology Nursing Forum, 46(2), 238-247. PMid:30767955. 
Alástico, G. P., \& Toledo, J. C. D. (2013). Acreditação Hospitalar: proposição de roteiro para implantação. Gestão \& Produção, 20(4), 815-831. http://dx.doi.org/10.1590/S0104$530 \times 2013005000011$.

Arksey, H., \& O'Malley, L. (2005). Scoping studies: towards a methodological framework. International Journal of Social Research Methodology, 8(1), 19-32. http://dx.doi.org/10.1080/1364557032000119616.

Banka, G., Edgington, S., Kyulo, N., Padilla, T., Mosley, V., Afsarmanesh, N., Fonarow, G. C., \& Ong, M. K. (2015). Improving patient satisfaction through physician education, feedback, and incentives. Journal of Hospital Medicine, 10(8), 497-502. http://dx.doi.org/10.1002/jhm.2373. PMid:26014339.

Beattie, M., Murphy, D. J., Atherton, I., \& Lauder, W. (2015). Instruments to measure patient experience of healthcare quality in hospitals: a systematic review. Systematic Reviews, 4(1), 97. http://dx.doi.org/10.1186/s13643-015-0089-0. PMid:26202326.

Beattie, M., Shepherd, A., Lauder, W., Atherton, I., Cowie, J., \& Murphy, D. J. (2016). Development and preliminary psychometric properties of the Care Experience Feedback Improvement Tool (CEFIT). BMJ Open, 6(6), e010101. http://dx.doi.org/10.1136/bmjopen2015-010101. PMid:27301482.

Brown, S. M., McBride, G., Collingridge, D. S., Butler, J. M., Kuttler, K. G., Hirshberg, E. L., Jones, J. P., Hopkins, R. O., Talmor, D., \& Orme, J. (2015). Validation of the Intermountain patient perception of quality (PPQ) survey among survivors of an intensive care unit admission: a retrospective validation study. BMC Health Services Research, 15(1), 155. http://dx.doi.org/10.1186/s12913-015-0828-x. PMid:25889073.

Bruyneel, L., Tambuyzer, E., Coeckelberghs, E., De Wachter, D., Sermeus, W., De Ridder, D., Ramaekers, D., Weeghmans, I., \& Vanhaecht, K. (2017). New instrument to measure hospital patient experiences in flanders. International Journal of Environmental Research and Public Health, 14(11), 1319. http://dx.doi.org/10.3390/ijerph14111319. PMid:29084160.

Bull, C. (2021). Patient satisfaction and patient experience are not interchangeable concepts. International Journal for Quality in Health Care, 33(1), mzab023.

Bustamante, J. C., \& Rubio, N. (2017). Measuring customer experience in physical retail environments. Journal of Service Management, 28(5), 884-913. http://dx.doi.org/10.1108/JOSM-06-2016-0142.

Caneiras, C., Jácome, C., Mayoralas-Alises, S., Ramon Calvo, J., Almeida Fonseca, J., Escarrabill, J., \& Winck, J. C. (2019). Patient experience in home respiratory therapies: where we are and where to go. Journal of Clinical Medicine, 8(4), 555. http://dx.doi.org/10.3390/jcm8040555. PMid:31022916.

Carter, J., Ward, C., Wexler, D., \& Donelan, K. (2018). The association between patient experience factors and likelihood of 30-day readmission: a prospective cohort study. BMJ Quality \& Safety, 27(9), 683-690. http://dx.doi.org/10.1136/bmjqs-2017-007184. PMid:29146680.

Chan, B., Goldman, L. E., Sarkar, U., Schneidermann, M., Kessell, E., Guzman, D., Critchfield, J., \& Kushel, M. (2015). The effect of a care transition intervention on the patient experience of older multi-lingual adults in the safety net: results of a randomized controlled trial. Journal of General Internal Medicine, 30(12), 1788-1794. http://dx.doi.org/10.1007/s11606-015-3362-y. PMid:25986136.

Cowen, M. E., Czerwinski, J., Kabara, J., Blumenthal, D. U., Kheder, S., \& Simmons, S. (2016). The risk-outcome-experience triad: mortality risk and the hospital consumer assessment of healthcare providers and systems survey. Journal of Hospital Medicine, 11(9), 628-635. http://dx.doi.org/10.1002/jhm.2611. PMid:27251217.

Doyle, C., Lennox, L., \& Bell, D. (2013). A systematic review of evidence on the links between patient experience and clinical safety and effectiveness. BMJ Open, 3(1), e001570. http://dx.doi.org/10.1136/bmjopen-2012-001570. PMid:23293244. 
Drennan, J., Duffield, C., Scott, A. P., Ball, J., Brady, N. M., Murphy, A., Dahly, D., Savage, E., Corcoran, P., Hegarty, J., \& Griffiths, P. (2018). A protocol to measure the impact of intentional changes to nurse staffing and skill-mix in medical and surgical wards. Journal of Advanced Nursing, 74(12), 2912-2921. http://dx.doi.org/10.1111/jan.13796. PMid:30019346.

Fisher, K. A., Smith, K. M., Gallagher, T. H., Huang, J. C., Borton, J. C., \& Mazor, K. M. (2019). We want to know: patient comfort speaking up about breakdowns in care and patient experience. BMJ Quality \& Safety, 28(3), 190-197. http://dx.doi.org/10.1136/bmjqs-2018008159. PMid:30269059.

Forcino, R. C., Barr, P. J., O'Malley, A. J., Arend, R., Castaldo, M. G., Ozanne, E. M., PercacLima, S., Stults, C. D., Tai-Seale, M., Thompson, R., \& Elwyn, G. (2018). Using Collabo RATE, a brief patient-reported measure of shared decision making: results from three clinical settings in the United States. Health Expectations, 21(1), 82-89. http://dx.doi.org/10.1111/hex.12588. PMid:28678426.

Garrard, F., \& Narayan, H. (2013). Assessing obstetric patient experience: a SERVQUAL questionnaire. International Journal of Health Care Quality Assurance, 26(7), 582-592. http://dx.doi.org/10.1108/IJHCQA-08-2011-0049. PMid:24167918.

Gillam, S. W., Gillam, A. R., Casler, T. L., \& Curcio, K. (2016). Education for medications and side effects: a two part mechanism for improving the patient experience. Applied Nursing Research, 31, 72-78.

Giordano, L. A., Elliott, M. N., Goldstein, E., Lehrman, W. G., \& Spencer, P. A. (2010). Development, implementation, and public reporting of the HCAHPS survey. Medical Care Research and Review : MCRR, 67(1), 27-37. http://dx.doi.org/10.1177/1077558709341065. PMid:19638641.

Heyworth, L., Rozenblum, R., Burgess, J. F., Jr., Baker, E., Meterko, M., Prescott, D., Neuwirth, Z., \& Simon, S. R. (2014). Influence of shared medical appointments on patient satisfaction: a retrospective 3-year study. Annals of Family Medicine, 12(4), 324-330. http://dx.doi.org/10.1370/afm.1660. PMid:25024240.

Jenkinson, C., Coulter, A., \& Bruster, S. (2002). The Picker Patient Experience Questionnaire: development and validation using data from in-patient surveys in five countries. International Journal for Quality in Health Care, 14(5), 353-358. http://dx.doi.org/10.1093/intqhc/14.5.353. PMid:12389801.

Jenkinson, C., Coulter, A., Reeves, R., Bruster, S., \& Richards, N. (2003). Properties of the Picker Patient Experience questionnaire in a randomized controlled trial of long versus short form survey instruments. Journal of Public Health Medicine, 25(3), 197-201. http://dx.doi.org/10.1093/pubmed/fdg049. PMid:14575193.

Kandampully, J., Zhang, T. C., \& Jaakkola, E. (2018). Customer experience management in hospitality. International Journal of Contemporary Hospitality Management, 30(1), 21-56. http://dx.doi.org/10.1108/IJCHM-10-2015-0549.

Kaneko, M., Aoki, T., Mori, H., Ohta, R., Matsuzawa, H., Shimabukuro, A., Motomura, K., \& Inoue, M. (2019). Associations of patient experience in primary care with hospitalizations and emergency department visits on isolated islands: a prospective cohort study. The Journal of Rural Health, 35(4), 498-505. http://dx.doi.org/10.1111/jrh.12342. PMid:30550635.

Kashif, M., Samsi, S. Z. M., Awang, Z., \& Mohamad, M. (2016). EXQ: measurement of healthcare experience quality in Malaysian settings. International Journal of Pharmaceutical and Healthcare Marketing, 10(1), 27-47. http://dx.doi.org/10.1108/IJPHM-03-2015-0011.

Keller, S., O'Malley, A. J., Hays, R. D., Matthew, R. A., Zaslavsky, A. M., Hepner, K. A., \& Cleary, P. D. (2005). Methods used to streamline the CAHPS $₫$ hospital survey. Health Services Research, 40(6p2), 2057-2077. http://dx.doi.org/10.1111/j.1475-6773.2005.00478.x. 
Kemp, K. A., Santana, M. J., Southern, D. A., McCormack, B., \& Quan, H. (2016). Association of inpatient hospital experience with patient safety indicators: a cross-sectional, Canadian study. BMJ Open, 6(7), e011242. http://dx.doi.org/10.1136/bmjopen-2016-011242. PMid:27371554.

Kerezoudis, P., Alvi, M. A., Ubl, D. S., Hanson, K. T., Krauss, W. E., Meyer, F. B., Spinner, R. J., Habermann, E. B., \& Bydon, M. (2018). The impact of spine disease, relative to cranial disease, on perception of health and care experience: an analysis of 1484 patients in a tertiary center. Journal of Neurosurgery, 129(6), 1630-1640. http://dx.doi.org/10.3171/2017.7.JNS17991. PMid:29372876.

Klaus, P. P., \& Maklan, S. (2013). Towards a better measure of customer experience. International Journal of Market Research, 55(2), 227-246. http://dx.doi.org/10.2501/IJMR-2013-021.

Kuis, E. E., \& Goossensen, A. (2017). Evaluating care from a care ethical perspective: a pilot study. Nursing Ethics, 24(5), 569-582. http://dx.doi.org/10.1177/0969733015620939. PMid:26811395.

Lane, J. V., Hamilton, D. F., MacDonald, D. J., Ellis, C., \& Howie, C. R. (2016). Factors that shape the patient's hospital experience and satisfaction with lower limb arthroplasty: an exploratory thematic analysis. BMJ Open, 6(5), e010871. http://dx.doi.org/10.1136/bmjopen-2015-010871. PMid:27217282.

Larsson, B. W., \& Larsson, G. (2002). Development of a short form of the Quality from the Patient's Perspective (QPP) questionnaire. Journal of Clinical Nursing, 11(5), 681-687. http://dx.doi.org/10.1046/j.1365-2702.2002.00640.x. PMid:12201896.

Larsson, G., Larsson, B. W., \& Munck, I. M. (1998). Refinement of the questionnaire 'quality of care from the patient's perspective'using structural equation modelling. Scandinavian Journal of Caring Sciences, 12(2), 111-118. PMid:9801632.

LaVela, S. L., \& Gallan, A. (2014). Evaluation and measurement of patient experience. Patient Experience Journal, 1(1), 28-36.

Lawton, R., O'Hara, J. K., Sheard, L., Reynolds, C., Cocks, K., Armitage, G., \& Wright, J. (2015). Can staff and patient perspectives on hospital safety predict harm-free care? An analysis of staff and patient survey data and routinely collected outcomes. BMJ Quality \& Safety, 24(6), 369-376. http://dx.doi.org/10.1136/bmjqs-2014-003691. PMid:25862755.

Leggat, S. G., Karimi, L., \& Bartram, T. (2017). A path analysis study of factors influencing hospital staff perceptions of quality of care factors associated with patient satisfaction and patient experience. BMC Health Services Research, 17(1), 739. http://dx.doi.org/10.1186/s12913-017-2718-x. PMid:29145847.

Levine, R. E., Fowler, F. J., Jr., \& Brown, J. A. (2005). Role of cognitive testing in the development of the CAHPS $®$ hospital survey. Health Services Research, 40(6p2), $2037-$ 2056. http://dx.doi.org/10.1111/j.1475-6773.2005.00472.x.

Liu, C., Wu, Y., \& Chi, X. (2017). Relationship preferences and experience of primary care patients in continuity of care: a case study in Beijing, China. BMC Health Services Research, 17(1), 585. http://dx.doi.org/10.1186/s12913-017-2536-1. PMid:28830507.

Lusilla-Palacios, P., \& Castellano-Tejedor, C. (2017). Acute spinal cord injury patients' satisfaction with care: results from an intervention study in a specialized rehabilitation unit. Journal of Health Psychology, 22(10), 1289-1299. http://dx.doi.org/10.1177/1359105315626785. PMid:26837691.

Macinati, M. S. (2008). The relationship between quality management systems and organizational performance in the Italian National Health Service. Health Policy, 85(2), 228241. http://dx.doi.org/10.1016/j.healthpol.2007.07.013. PMid:17825941.

Maklan, S. (2012). EXQ: a multiple-item scale for assessing service experience. Journal of Service Management, 23(1), 5-33. http://dx.doi.org/10.1108/09564231211208952.

Male, L., Noble, A., Atkinson, J., \& Marson, T. (2017). Measuring patient experience: a systematic review to evaluate psychometric properties of patient reported experience 
measures (PREMs) for emergency care service provision. International Journal for Quality in Health Care, 29(3), 314-326. http://dx.doi.org/10.1093/intqhc/mzx027. PMid:28339923.

Malik, N., Alvaro, C., Kuluski, K., Wilkinson, A. J., \& Hurst, K. (2016). Measuring patient satisfaction in complex continuing care/rehabilitation care. International Journal of Health Care Quality Assurance, 29(3), 324-336. http://dx.doi.org/10.1108/IJHCQA-07-2015-0084. PMid:27120509.

Mbama, C. I., \& Ezepue, P. O. (2018). Digital banking, customer experience and bank financial performance. International Journal of Bank Marketing, 36(2), 230-255. http://dx.doi.org/10.1108/IJBM-11-2016-0181.

McColl-Kennedy, J. R., Gustafsson, A., Jaakkola, E., Klaus, P., Radnor, Z. J., Perks, H., \& Friman, M. (2015). Fresh perspectives on customer experience. Journal of Services Marketing, 29(6-7), 430-435. http://dx.doi.org/10.1108/JSM-01-2015-0054

McFarlan, S., O’Brien, D., \& Simmons, E. (2019). Nurse-leader collaborative improvement project: improving patient experience in the emergency department. Journal of Emergency Nursing: JEN, 45(2), 137-143. http://dx.doi.org/10.1016/j.jen.2018.11.007. PMid:30591243.

McLean, C., Griffiths, P., Mesa-Eguiagaray, I., Pickering, R. M., \& Bridges, J. (2017). Reliability, feasibility, and validity of the quality of interactions schedule (QuIS) in acute hospital care: an observational study. BMC Health Services Research, 17(1), 380. http://dx.doi.org/10.1186/s12913-017-2312-2. PMid:28569151.

Mendes, G. H. D. S., \& Mirandola, T. B. D. S. (2015). Acreditação hospitalar como estratégia de melhoria: impactos em seis hospitais acreditados. Gestão \& Produção, 22(3), 636-648. http://dx.doi.org/10.1590/0104-530X1226-14.

Mendes, G. H., Oliveira, M. G., Gomide, E. H., \& Nantes, J. F. D. (2017). Uncovering the structures and maturity of the new service development research field through a bibliometric study (1984-2014). Journal of Service Management, 28(1), 182-223. http://dx.doi.org/10.1108/JOSM-07-2015-0230.

Merlino, J. I., Kestranek, C., Bokar, D., Sun, Z., Nissen, S. E., \& Longworth, D. L. (2014). HCAHPS survey results: impact of severity of illness on hospitals' performance on HCAHPS survey results. Journal of Patient Experience, 1(2), 16-21. http://dx.doi.org/10.1177/237437431400100204. PMid:28725804.

Meyer, C., \& Schwager, A. (2007). Understanding customer experience. Harvard Business Review, 85(2), 116-126, 157. PMid:17345685.

Mosavi, S. M., Sangari, M. S., \& Keramati, A. (2018). An integrative framework for customer switching behavior. Service Industries Journal, 38(15-16), 1067-1094. http://dx.doi.org/10.1080/02642069.2018.1428955.

Murrells, T., Robert, G., Adams, M., Morrow, E., \& Maben, J. (2013). Measuring relational aspects of hospital care in England with the 'Patient Evaluation of Emotional Care during Hospitalisation'(PEECH) survey questionnaire. BMJ Open, 3(1), e002211. http://dx.doi.org/10.1136/bmjopen-2012-002211. PMid:23370012.

O’Malley, A. J., Zaslavsky, A. M., Hays, R. D., Hepner, K. A., Keller, S., \& Cleary, P. D. (2005). Exploratory factor analyses of the CAHPS $®$ hospital pilot survey responses across and within medical, surgical, and obstetric services. Health Services Research, 40(6p2), 20782095. http://dx.doi.org/10.1111/j.1475-6773.2005.00471.x.

Oltedal, S., Garratt, A., Bjertnæs, Ø., Bjørnsdottìr, M., Freil, M., \& Sachs, M. (2007). The NORPEQ patient experiences questionnaire: data quality, internal consistency and validity following a Norwegian inpatient survey. Scandinavian Journal of Public Health, 35(5), 540547. http://dx.doi.org/10.1080/14034940701291724. PMid:17852989.

Otani, K., Buchanan, P. R., Desai, S. P., \& Herrmann, P. A. (2016). Different combining process between male and female patients to reach their overall satisfaction. Journal of Patient Experience, 3(4), 145-150. http://dx.doi.org/10.1177/2374373516685953. PMid:28725851. 
Parasuraman, A., Zeithaml, V. A., \& Berry, L. L. (1988). Servqual: a multiple-item scale for measuring consumer perc. Journal of Retailing, 64(1), 12.

Peterson, J., Pearce, P. F., Ferguson, L. A., \& Langford, C. A. (2017). Understanding scoping reviews: Definition, purpose, and process. Journal of the American Association of Nurse Practitioners, 29(1), 12-16. http://dx.doi.org/10.1002/2327-6924.12380. PMid:27245885.

Pettersen, K. I., Veenstra, M., Guldvog, B., \& Kolstad, A. (2004). The Patient Experiences Questionnaire: development, validity and reliability. International Journal for Quality in Health Care, 16(6), 453-463. http://dx.doi.org/10.1093/intqhc/mzh074. PMid:15557355.

Pine, B. J., 2nd, \& Gilmore, J. H. (1998). Welcome to the experience economy. Harvard Business Review, 76(4), 97-105. PMid:10181589.

Pottenger, B. C., Davis, R. O., Miller, J., Allen, L., Sawyer, M., \& Pronovost, P. J. (2016). Comprehensive unit-based safety program (CUSP) to improve patient experience: how a hospital enhanced care transitions and discharge processes. Quality Management in Health Care, 25(4), 197-202. http://dx.doi.org/10.1097/QMH.0000000000000106. PMid:27749716.

Rao, K. D., Peters, D. H., \& Bandeen-Roche, K. (2006). Towards patient-centered health services in India: a scale to measure patient perceptions of quality. International Journal for Quality in Health Care, 18(6), 414-421. http://dx.doi.org/10.1093/intqhc/mzl049. PMid:17012306.

Rapport, F., Hibbert, P., Baysari, M., Long, J. C., Seah, R., Zheng, W. Y., Jones, C., Preece, K., \& Braithwaite, J. (2019). What do patients really want? An in-depth examination of patient experience in four Australian hospitals. BMC Health Services Research, 19(1), 38. http://dx.doi.org/10.1186/s12913-019-3881-z. PMid:30646962.

Reeves, R., Coulter, A., Jenkinson, C., Cartwright, J., Bruster, S., \& Richards, N. (2002). Development and pilot testing of questionnaires for use in the acute NHS trust inpatient survey programme. Oxford: Picker Institute.

Rodrigues, K. C. (2019). A era da experiência dos pacientes. GV EXECUTIVO, 18(1), 16-19. http://dx.doi.org/10.12660/gvexec.v18n1.2019.78186.

Roseen, E. J., Cornelio-Flores, O., Lemaster, C., Hernandez, M., Fong, C., Resnick, K., Wardle, J., Hanser, S., \& Saper, R. (2017). Inpatient massage therapy versus music therapy versus usual care: a mixed-methods feasibility randomized controlled trial. Global Advances in Health and Medicine, 6, X17735816. http://dx.doi.org/10.1177/2164957X17735816. PMid:29085740.

Rubens, F. D., Rothwell, D. M., Al Zayadi, A., Sundaresan, S., Ramsay, T., \& Forster, A. (2018). Impact of patient characteristics on the Canadian Patient Experiences SurveyInpatient Care: survey analysis from an academic tertiary care centre. BMJ Open, 8(8), e021575. http://dx.doi.org/10.1136/bmjopen-2018-021575. PMid:30166297.

Sanyal, D. K., Bhowmick, P. K., \& Das, P. P. (2021). A review of author name disambiguation techniques for the PubMed bibliographic database. Journal of Information Science, 47(2), 227-254. http://dx.doi.org/10.1177/0165551519888605.

Silva, B. B., Mergulhão, R. C., Favoretto, C., \& Mendes, G. H. (2018). Critical success factors of Six Sigma implementations in companies in Brazil. International Journal of Lean Six Sigma, 10(2), 143-160.

Silva, J. H. O., Mendes, G. H. S., Cauchick Miguel, P. A., Amorim, M., \& Teixeira, J. G. (2021). Customer experience research: intellectual structure and future research opportunities. Journal of Service Theory and Practice, 31(6), 893-931. http://dx.doi.org/10.1108/JSTP-08-2020-0193.

Sofaer, S., Crofton, C., Goldstein, E., Hoy, E., \& Crabb, J. (2005). What do consumers want to know about the quality of care in hospitals? Health Services Research, 40(6p2), 20182036. http://dx.doi.org/10.1111/j.1475-6773.2005.00473.x. PMid:16316436.

The Beryl Institute. (2020). Defining patient experience. Retrieved in 2020, January 15, from http://www.theberylinstitute.org/?page=DefiningPatientExp 
Toomey, S. L., Zaslavsky, A. M., Elliott, M. N., Gallagher, P. M., Fowler, F. J., Jr., Klein, D. J., Shulman, S., Ratner, J., McGovern, C., LeBlanc, J. L., \& Schuster, M. A. (2015). The development of a pediatric inpatient experience of care measure: child HCAHPS ${ }$. Pediatrics, 136(2), 360-369. http://dx.doi.org/10.1542/peds.2015-0966. PMid:26195542.

van den Hombergh, P., van Doorn-Klomberg, A., Campbell, S., Wensing, M., \& Braspenning, J. (2016). Patient experiences with family medicine: a longitudinal study after the Dutch health care reforms in 2006. BMC Family Practice, 17(1), 118. http://dx.doi.org/10.1186/s12875016-0519-7. PMid:27561993.

Verhoef, P. C., Franses, P. H., \& Hoekstra, J. C. (2002). The effect of relational constructs on customer referrals and number of services purchased from a multiservice provider: does age of relationship matter? Journal of the Academy of Marketing Science, 30(3), 202-216. http://dx.doi.org/10.1177/0092070302303002.

Verhoef, P. C., Lemon, K. N., Parasuraman, A., Roggeveen, A., Tsiros, M., \& Schlesinger, L. A. (2009). Customer experience creation: Determinants, dynamics and management strategies. Journal of Retailing, 85(1), 31-41. http://dx.doi.org/10.1016/j.jretai.2008.11.001.

Wallace, S., Hanson, K. T., Dowdy, S. C., \& Habermann, E. B. (2018). Impact of surgical approach and patient factors on Hospital Consumer Assessment of Healthcare Providers and Systems (HCAHPS) survey scoring in gynecologic surgery. Gynecologic Oncology, 148(1), 28-35. http://dx.doi.org/10.1016/j.ygyno.2017.11.015. PMid:29221835.

Wardhani, V., Utarini, A., van Dijk, J. P., Post, D., \& Groothoff, J. W. (2009). Determinants of quality management systems implementation in hospitals. Health Policy, 89(3), 239-251. http://dx.doi.org/10.1016/j.healthpol.2008.06.008. PMid:18752866.

Webster, C. S., Jowsey, T., Lu, L. M., Henning, M. A., Verstappen, A., Wearn, A., Reid, P. M., Merry, A. F., \& Weller, J. M. (2019). Capturing the experience of the hospital-stay journey from admission to discharge using diaries completed by patients in their own words: a qualitative study. BMJ Open, 9(3), e027258. http://dx.doi.org/10.1136/bmjopen-2018027258. PMid:30862638.

Wiig, S., Storm, M., Aase, K., Gjestsen, M. T., Solheim, M., Harthug, S., Robert, G., \& Fulop, N. (2013). Investigating the use of patient involvement and patient experience in quality improvement in Norway: rhetoric or reality? BMC Health Services Research, 13(1), 206. http://dx.doi.org/10.1186/1472-6963-13-206. PMid:23742265.

Wilde, B., Starrin, B., Larsson, G., \& Larsson, M. (1993). Quality of care from a patient perspective: a grounded theory study. Scandinavian Journal of Caring Sciences, 7(2), 113120. http://dx.doi.org/10.1111/j.1471-6712.1993.tb00180.x. PMid:8248668.

Wolf, C. P. X. P., \& Jason, A. (2014). Defining patient experience. Patient Experience Journal, 1(1), 7-19. http://dx.doi.org/10.35680/2372-0247.1000.

Wolf, C. P. X. P., \& Jason, A. (2019). The future of patient experience: Five thoughts on where we must go from here. Patient Experience Journal, 6(3), 1-4.

Wong, E. L., Coulter, A., Cheung, A. W., Yam, C. H., Yeoh, E. K., \& Griffiths, S. (2013). Validation of inpatient experience questionnaire. International Journal for Quality in Health Care, 25(4), 443-451. http://dx.doi.org/10.1093/intghc/mzt034. PMid:23690442.

Wong, E. L., Coulter, A., Hewitson, P., Cheung, A. W., Yam, C. H., Lui, S. F., Tam, W. W., \& Yeoh, E. K. (2015). Patient experience and satisfaction with inpatient service: development of short form survey instrument measuring the core aspect of inpatient experience. PLoS One, 10(4), e0122299. http://dx.doi.org/10.1371/journal.pone.0122299. PMid:25860775. 